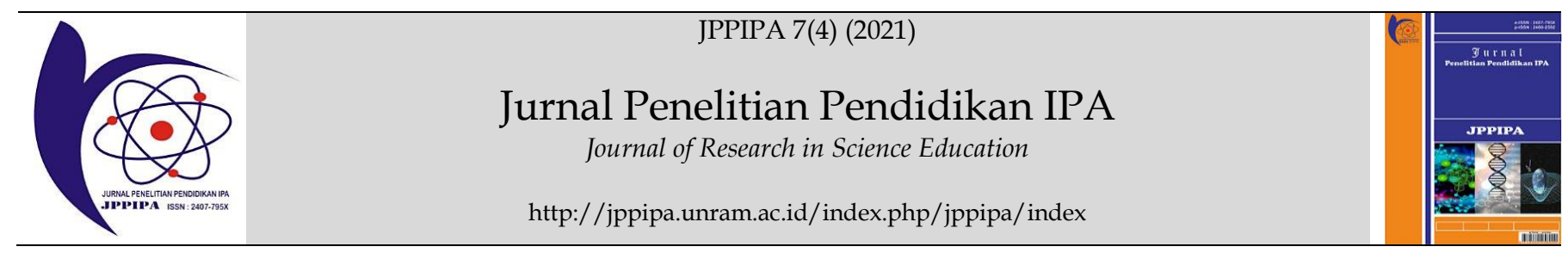

\title{
Effectiveness of Mechanical Wave Learning Material Based on ICT Integrated CTL to Improve Students Learning Outcomes
}

\author{
Asrizal $^{1 *}$, Auvi Winandri Utami² \\ ${ }^{1}$ Department of Physics, Faculty of Mathematics and Natural Sciences, Padang State University, Padang, Indonesia. \\ ${ }^{2}$ Physics Education Study Program, Faculty of Mathematics and Natural Sciences, Padang State University, Padang, Indonesia.
}

DOI: $10.29303 /$ jppipa.v7i4.837

\section{Article Info}

Received: July 12th, 2021

Revised: August 28th 2021

Accepted: October 9th 2021

\begin{abstract}
The 21st-century skills integrate life career skills, learning and innovation-4C, and information, media, and technology skills. The components are required to make the learning process more effective and efficient. 21st-century learning is transforming from teacher center to student center. Student-centered learning can use ICT-based learning material in the learning process. Based on preliminary research, the use of ICT-based learning material was still low. The solution to this problem was developing learning material based on ICT integrated CTL to improve student's learning outcomes. The method that used in this research was quasi-experiment. The sample in the field testing of learning material based on ICT was a grade XI of students at SMAN Lubuk Sikaping. The data collection instruments used were attitude observation sheets, written tests, and performance assessment sheets. The data analysis techniques used were descriptive statistical analysis, normality test, homogeneity test, and t-test. Based on data analysis, it can be stated that the application of mechanical wave learning material based on ICT integrated CTL has a significant effect on students' learning outcomes, including in the aspects of attitudes, knowledge, and skills. This result indicates that the use of mechanical wave learning material based on ICT integrated CTL effectively improves students' learning outcomes.
\end{abstract}

Keywords: Learning material; ICT; Mechanical wave; CTL

Citation: Asrizal, A., \& Utami, A.W. (2021). Effectiveness of Mechanical Wave Learning Material Based on ICT Integrated CTL to Improve Students Learning Outcomes. Jurnal Penelitian Pendidikan IPA, 7(4), 632-641. doi:https://doi.org/10.29303/jppipa.v7i4.837

\section{Introduction}

Learning in 21st-century is centered on the development of the 4.0 era industrial revolution. The implementation of 21st-century learning combines the literacy skills, knowledge, and mastery of technology to face the development of the globalization era. In 21st century learning, students are required to be active in the learning process (Desnita, 2021). Students are required to build their abilities so that learning is not just the transfer of knowledge from the teacher to the student but the students themselves who build their knowledge. Learning will be more meaningful if students are directly involved in finding concepts in the learning process.

The application of 21st-century learning should be able to develop students' $4 \mathrm{C}$ skills, namely critical thinking, creativity, communication, and collaboration (Redhana, 2019). Every student requires these 4C skills to compete with other students so that they can meet their needs. The skills that students must have must be developed so that Human Resources (HR) increases every year and have high competitiveness. The progress of a nation depends on the quality of the nation's Human Resources (HR). Quality human resources are one of the main assets in the progress of a 
nation, both in the fields of economy, science and technology, politics, culture, and national character.

Information and Communication Technology (ICT) is experiencing rapid development in the field of education. The utilization of ICT in education can help the learning process such as presentations, independent learning media such as e-learning, e-learning material, and ICT-based learning material. Physics learning in schools can be supported by ICT-based learning tools that make it easier for students to visualize physics learning material that cannot be seen directly. One of the learning tools that can be used is ICT-based learning material.

The importance of using learning material based on ICT in 21st-century learning is to assist teachers in carrying out the learning process. Learning materials are designed as tools that can help students and teachers in learning so that learning is more effective (Olayinka, 2016). ICT-based learning material provides benefits for teachers and students in learning. The benefits of ICT-based learning material for teachers are: saving time in learning, changing the role of the teacher to become a facilitator, and improving the learning process to be more effective and interactive. On the other hand, the benefits of ICT-based teaching materials for students include: reducing dependence on teachers in learning, being able to learn without being limited by time and place, being able to learn at their own pace, being able to learn in the order chosen, and helping potential to become independent learning (Asrizal et al., 2018)

The real conditions found in the field are not in accordance with the expected ideal conditions. Three preliminary study results were obtained based on the initial study conducted at SMA N 1 Lubuk Sikaping. First, the use of CTL-integrated ICT-based learning material. The instrument used is a questionnaire on the use of ICT-based integrated CTL learning material. The results of the questionnaire distribution obtained an average value of 54 , which was in the low category. Second, students' thinking skills. The instrument for this second real condition was done by giving several questions in the form of discourse to class XI MIPA students at SMA N 1 Lubuk Sikaping, which consisted of seven classes through Google classroom. The average value obtained from giving questions for seven classes is 58, which is in enough category. Third, student learning outcomes were obtained from the Student Mid-Semester Examination (UTS) scores for class XI SMA students in the 2019/2020 academic year semester 1 . The average value obtained for the seven classes is 60 , which is in enough category.

Based on the initial study conducted, there was a gap between the expected ideal conditions and the conditions in the field. This implies that there is a problem in research that needs to be solved. One solution is to develop mechanical wave learning material based on ICT integrated of CTL to Improve learning outcomes of class XI high school students.

The research conducted has differences from previous research. Research conducted by Astuti, 2015 with the title "Development of Contextual Teaching and Learning (CTL) Based Learning Material on Elasticity Material at MAN 4 Aceh Besar" uses printed media learning material so that they are not in accordance with the needs of the 21st century. Learning material also integrated the CTL approach but did not use the REACT strategy. Learning material based on ICT can be used by teachers and students anytime and anywhere as long as they are connected to the internet network. The advantages of learning material based on ICT include providing ease of use for students in the learning process, changing the role of students from being passive to being active, students can study or study learning material at any time.

Learning materials based on ICT are learning materials that utilize ICT tools to process, store and manipulate data so that the information produced is of high quality (Usman et al., 2020). Learning material supports media in implementing learning activities to improve student's abilities (Asrizal et al., 2017). The preparation of ICT-based learning material must meet the established rules. The stage of preparing learning material consists of five. First, the planning stage which aims to determine the characteristics of the core competence and basic competence of a subject whether learning can be developed using ICT-based learning material. Second, the preparation stage consists of determining the material, the type of software, the type of ICT-based learning material, and compiling storyboards. Third, the preparation stage depends on the characteristics of the material to be developed in the learning activities. Fourth, the assessment stage evaluates the learning material that has been prepared, whether they meet the requirements or need improvement. Fifth, the delivery stage is to submit ICTbased learning material to the person in charge of implementing the school (Usman et al., 2020).

The learning materials based on ICT have several advantages and disadvantages. The advantages of the learning material based on ICT include providing convenience for students in the learning process, changing the role of students from being passive to being active, tudents being able to study or reviewing teaching materials at any time, educators and students can use learning material or learning instructions that structured and scheduled through an intranet or internet network so that both can assess each other to what extent learning material are studied, the availability of e-moderating facilities where educators 
and students can communicate easily through internet facilities regularly without being limited by distance, place and time. In the classroom, educators can supervise students' learning process where the time and place have been set. Unlike the case outside the classroom, students can use learning material based on ICT where they learn at the time and speed they want.

In addition to having advantages, learning material based on ICT also have weaknesses in their use. The weaknesses of ICT-based learning material are that educators must have ICT skills. The lack of adaptability of schools to technological advances, the ability of schools to manage sustainable facilities requires a deep ability of teachers to understand ICT and freedom that educators cannot limit to students in terms of a network of social media sites (Sunardi, 2017). The use of learning material based on ICT by students is under the guidance of the teacher to minimize existing weaknesses.

One of the physics learning materials that can use ICT-based learning material is wave mechanics. A wave is the propagation of vibration energy that propagates through a medium or without going through a medium (Halliday, 2010). Waves are defined as vibrations that propagate through an intermediary medium (Yana et al., 2019). A wave is a vibration or disturbance that propagates. The propagation of the disturbance is the propagation of energy, while the particles of the medium do not propagate along. Waves can be grouped into several types. First, based on the direction of vibration, waves are grouped into two, namely transverse waves and longitudinal waves. Second, based on the propagation medium, the wave consists of two, namely mechanical and electromagnetic waves. Third, based on the amplitude, the waves are grouped into two, namely traveling waves and stationary (silent) waves (Foster, 2017: 261).

Waves have various properties. The physical properties of waves consist of reflection, refraction, wave interference, and wave diffraction. Reflection is the reversal of a wave back to its original medium. When a wave hits a barrier, it is reflected. Refraction is the bending of a wave at the boundary of two different mediums so that some of the energy of the wave will be reflected and part of it will be refracted. Wave interference is a combination or superposition when two or more waves are in the same place at the same time. Wave diffraction is a bending or bending event that occurs when a wave passes through a hole in a barrier with a hole diameter smaller than the wavelength. The smaller the hole in the barrier compared to the wavelength of the wave, the greater the deflection (Sutopo, 2016).

The CTL approach helps students to relate learning material to students' real lives (Khairunnisa et al., 2020). CTL actively engages students in learning and helps students connect learning materials with real-world contexts (Kadmayana et al., 2021). The use of the CTL approach in ICT-based learning material can help students learn through experience, not just rote memorization, because learning is not a collection of facts and concepts that students directly accept, but that knowledge must be constructed by students themselves (Jauhari, 2011).

The learning materials based on ICT integrated CTL have several advantages. First, the mechanical wave material presented in the learning material based on ICT is associated with students' real lives so that students are easier to understand the learning material. Second, it can increase students' interest in learning physics because the learning material used are interactive, so that they provide feedback for students. Third, it can optimize the assessment of student's creative thinking skills

Based on the results of the initial study and the background that has been described, the title of this research is "The Effectiveness of Mechanical Wave Learning Material Based ICT Integrated CTL to Improve Learning Outcomes of Class XI High School Students." The approach used is the CTL approach using the REACT strategy, while thinking skills are limited to students' creative thinking skills. This study aimed to determine the effectiveness of mechanical wave learning material based on ICT integrated CTL to improve student's learning outcomes.

\section{Method}

The research method in testing the learning material based on ICT was quasi-experimental. This method was chosen in this testing activity because of the difficulty of controlling all variables that affect student learning outcomes. The way students learn at home, the time students learn independently at home, and the time students do assignments at home can't be controlled properly. The independent variable in this research was mechanical wave learning material based on ICT, while the dependent variable was students' learning outcomes.

Before implementing the learning material based on ICT integrated CTL, a validation test was conducted. Five experts from a Physics lecturer carried out the validation of this learning material. The average value of the validation of learning material based on ICT integrated CTL is 87.37. The average value of this validation can be classified into the very good category. Revision of the learning material based on ICT was carried out based on expert advice, including technical instructions for using the learning material based on 
ICT, adding videos for minimum and maximum interference events of a mechanical wave, and adding reference books related to mechanical wave. The cover display of the learning material based on ICTintegrated on CTL which is used in the testing activities, can be seen in Figure 1.

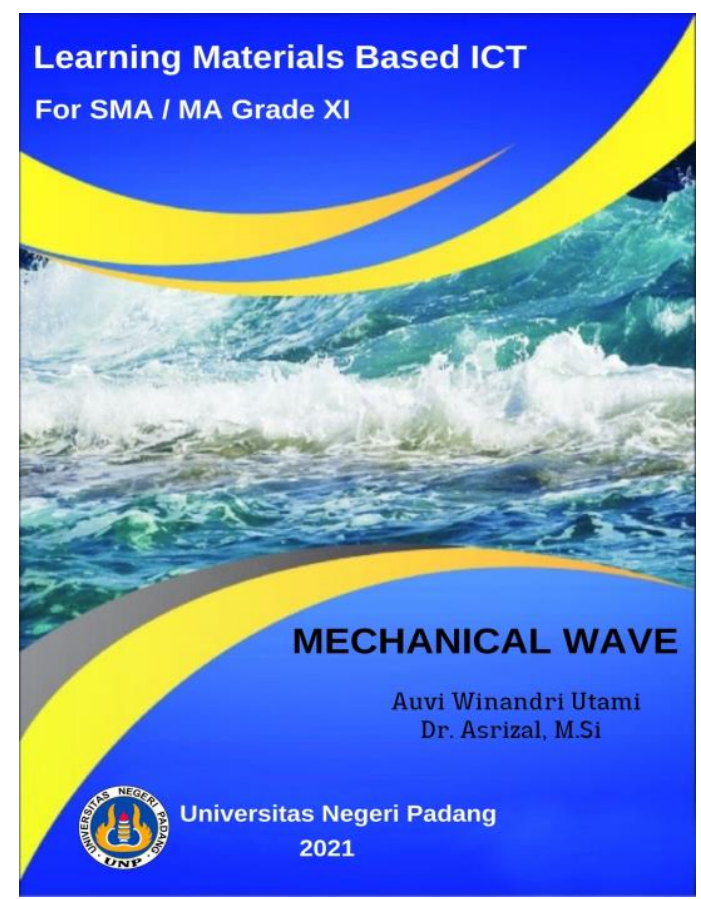

Figure 1. Cover of Learning Material Based on ICT

Research design can be incorporated into the before and after design for a single sample group. Before implementing the learning material based on ICT integrated CTL, physics learning was conducted for four meetings. Data of attitudes and creative thinking skills were taken during the learning process. At the end of the activity, a post-test was conducted to measure the knowledge of students. After that, the learning material based on ICT integrated CTL was implemented in physics learning for four meetings. Data of attitudes and creative thinking skills of students were measured during the implementation of this learning material. After implementing the learning material based on ICT integrated CTL, a post-test was given to measure students' knowledge. The experimental design model before and after the use of learning material based on ICT integrated CTL for one sample group is shown in Figure 2.

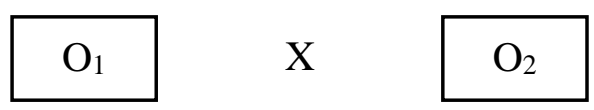

Figure 2. Before-After Experiment Design

Here $\mathrm{O}_{1}$ is the value of a group of students before treatment, $\mathrm{X}$ is the treatment, and $\mathrm{O}_{2}$ is the value of students after treatment.
The population in the testing activity of using the learning material based on ICT integrated CTL were all students of grade XI at SMAN Lubuk Sikaping. There were seven classes in XI with a total of 248 students. The sample in the testing activity of using the learning material based on ICT integrated CTL were students of grade XI MIPA 2. The number of students as a sample was 32 students.

In the activity of testing the effectiveness of using learning material based on ICT integrated CTL, three instruments were used to collect the data. The instrument to measure the attitudes aspect of students was an attitude observation sheet. Attitude indicators consist of six indicators, namely discipline, confidence, hard work, cooperation, responsibility, and tolerance. The instrument for measuring the knowledge aspect of students was a written test in the form of multiple choice. The instrument for measuring the creative skills of students was a performance assessment sheet. Creative skill indicators include generating many ideas or concepts, giving many ways or suggestions, and thinking in unusual ways.

The research data were analyzed by descriptive statistics and comparison tests for the one-sample group. Normality tests and homogeneity tests were carried out before testing the hypothesis. Paired comparison test for one sample group was used if the data had a normal distribution and both groups of data before and after treatment had the same variance. On the other hand, the Wilcoxon signed-rank test was used if the data didn't have a normal distribution or the two groups of data didn't have the same variance.

\section{Result and Discussion}

\section{Result}

The results of the study can be seen in three aspects, namely aspects of attitudes, knowledge, and creative thinking skills. The first is the result of research on the aspect of knowledge. The results of data analysis will be described as follows.

\section{The Effect of Learning Material Based on ICT Integrated CTL on Attitude Aspect}

Assessment of student attitudes before and after using learning material based on ICT integrated CTL was carried out at each meeting using observation sheets. Attitude is defined as a reaction or response that arises from an individual to an object which then gives rise to individual behavior towards the object in certain ways. Observations before using learning material based on ICT integrated CTL were carried out in five meetings. Attitudes observed during learning activities using ICT-based learning material integrated CTL include discipline (ID), self-confidence (SC), hard work 
(HW), cooperation (CO), responsibility (RE), and tolerance (TL). Attitude observations were made before and after using the based learning material based on integrated CTL to determine the significant differences in the students' attitude scores. The results of observing student attitudes can be seen in Figure 3.

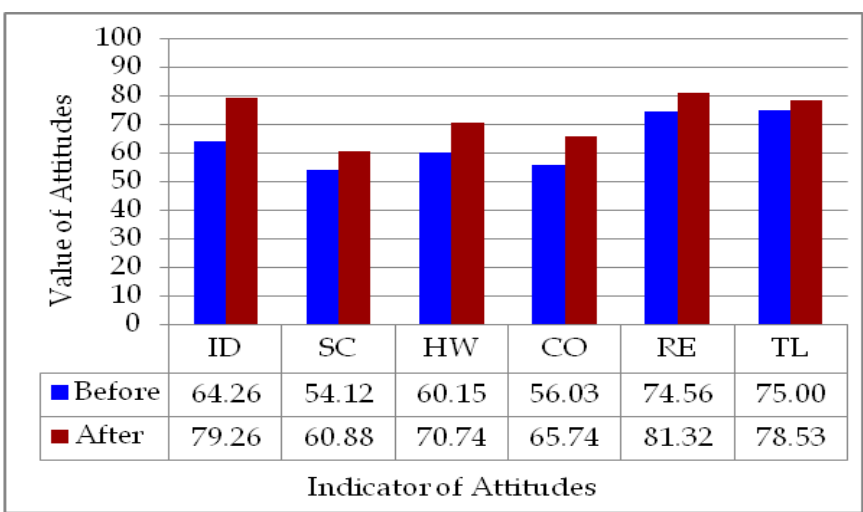

Figure 3. The Average Value of Observed Student's Attitudes

Based on the data analysis in Figure 3, it can be seen that the value of students' attitudes after using learning material for every indicator is higher than before using it. The significance of the difference in student attitudes before and after using the learning material based on ICT integrated CTL can be seen in Table 1.

Table 1. Results of Attitude Aspect Data Analysis

\begin{tabular}{llll}
\hline No & $\begin{array}{l}\text { Statistical } \\
\text { Parameter }\end{array}$ & $\begin{array}{l}\text { Value } \\
\text { Attitude } \\
\text { Before }\end{array}$ & $\begin{array}{l}\text { Value } \\
\text { Attitude } \\
\text { After }\end{array}$ \\
\hline 1 & Average & 62.10 & 76.06 \\
2 & Standard deviation & 6.88 & 8.01 \\
3 & Variance & 47.40 & 64.18 \\
4 & Mode & 60.00 & 75.00 \\
5 & $\begin{array}{l}\text { Lovalue of } \\
\text { normality test }\end{array}$ & 0.10 & 0.08 \\
6 & $\begin{array}{l}\text { L } \text { value of } \\
\text { normality test }\end{array}$ & 0.16 & \\
7 & $\begin{array}{l}\mathrm{F}_{\mathrm{c}} \text { value of } \\
\text { homogeneity test }\end{array}$ & 1.35 & \\
8 & $\begin{array}{l}\mathrm{F}_{\mathrm{t}} \text { value of } \\
\text { homogeneity test }\end{array}$ & 1.84 & \\
9 & $\begin{array}{l}\text { hom } \\
10\end{array}$ & -9.17 & \\
\hline
\end{tabular}

Based on the data analysis in Table 1, it can be explained that there was an increase in the average value of students' attitudes after using learning material, namely 62.10 and 76.06. The standard deviation values before and after using learning material were 6.88 and 8.01 . The variance values of students' attitudes before and after the use of learning material were 47.40 and 64.18.
Based on the attitude data that has been obtained, the data normality must be tested first. This is done to see if the two data are normally distributed. The normality test used is the Lilliefors test. The normality test results for attitudes before and after using learning material that has been carried out are obtained from the prices of $\mathrm{L}_{o}$ and $\mathrm{L}_{t}$ at a significant level (a) of 0.05 for $n=30$. The $L_{o}$ value for the attitude before is 0.10 , while the $L_{o}$ value for the attitude after is 0.08 . From the data obtained, the value of $\mathrm{L}_{\mathrm{o}}<\mathrm{L}_{\mathrm{t}}$ means that the attitude value data before and after learning material use are normally distributed.

After the normality test was carried out, the homogeneity test was then carried out. In this study, the total number of students was 30 people, so it can be obtained that the degree of freedom is $\mathrm{df}=\mathrm{n}-1=30-1=$ 29 . The $F_{t}$ value of 1.84 is obtained from the value of the degrees of freedom before and after the use of learning material, which is 29 . The value is 29 . $F_{c}$ is obtained from the highest value of variance divided by the lowest value of variance. The data found that $F_{c}<F_{t}$ so that the data on the attitude aspect values before and after the use of physics learning material were homogeneous.

Based on these data, the data can be declared normally distributed and homogeneous so that the statistics used are parametric statistics, namely the correlation comparison test. Correlation comparisons are useful to prove the significance of differences in student attitudes before and after using the learning material based on ICT integrated CTL. The analysis used is the product-moment equation. The results of the attitude analysis with the correlation coefficient test $(\mathrm{r})$ obtained from the equation is 0.54 .

The value of $t_{c}$ can be obtained using a correlated $t$-test so that the $t_{c}$ value obtained is -9.17 . Determination of the value of $t_{c}$ is determined by finding the degrees of freedom first. The value of the degrees of freedom is obtained from the number of students participating in the study minus one, so $\mathrm{dk}=$ $30-1=29$. The degrees of freedom $(\mathrm{df})=29$, and the " $t$ " value at the significant level at $5 \%$ is 2.04 , then the $t_{t}$ obtained is -2.04. In the test conducted using the lefthand side test, the $t_{h}$ value is smaller than the $t_{t}$ value $\left(t_{c}<t_{t}\right)$, then the working hypothesis is accepted. The value of $t_{h}$ is in the $\mathrm{H}_{\mathrm{o}}$ reject area. This shows that there is a significant difference between students' attitudes before and after using physics learning material. So, it can be concluded that learning material based on ICT integrated CTL is effectively used to improve student attitudes aspect. 
The Effect of Learning Material Based on ICT Integrated CTL on Knowledge Aspect

Aspects of student knowledge can be determined by conducting tests before and after the use of learning material based on ICT integrated CTL. Students do the test by answering the description questions for the test before and after the use of learning material with a lot of 2-point questions. The number of students who took the test was 30 people. Data on student learning outcomes before and after using the learning material based on ICT integrated CTL can be seen in Table 2 .

Table 2. Results of Knowledge Aspect Data Analysis

\begin{tabular}{|c|c|c|c|}
\hline No & $\begin{array}{l}\text { Statistical } \\
\text { Parameter }\end{array}$ & $\begin{array}{l}\text { Value } \\
\text { Knowledge } \\
\text { Before }\end{array}$ & $\begin{array}{l}\text { Value } \\
\text { Knowledge } \\
\text { After }\end{array}$ \\
\hline 1 & Average & 51.43 & 69.76 \\
\hline 2 & Standard deviation & 6.29 & 8.30 \\
\hline 3 & Variance & 39.63 & 69.01 \\
\hline 4 & Mode & 60.00 & 65.00 \\
\hline 5 & $\begin{array}{l}\mathrm{L}_{\mathrm{o}} \text { value of } \\
\text { normality test }\end{array}$ & 0.11 & 0.08 \\
\hline 6 & $\begin{array}{l}\mathrm{L}_{\mathrm{t}} \text { value of } \\
\text { normality test }\end{array}$ & 0.16 & \\
\hline 7 & $\begin{array}{l}\mathrm{F}_{\mathrm{c}} \text { value of } \\
\text { homogeneity test }\end{array}$ & 1.74 & \\
\hline 8 & $\begin{array}{l}F_{t} \text { value of } \\
\text { homogeneity test }\end{array}$ & 1.84 & \\
\hline 9 & $t_{c}$ value & -10.80 & \\
\hline 10 & $t_{t}$ value & -2.04 & \\
\hline
\end{tabular}

Based on the data analysis in Table 2, it can be explained that there was an increase in students' knowledge of the average value of students after using learning material based on ICT integrated CTL from 51.43 to 69.76 . The value of the standard deviation before and after is obtained from the value of the variance. The variance values before and after using learning material were 39.63 and 69.01 .

The data obtained must be tested for normality of the data first. This is to see if the data is normally distributed or not. The normality test used is the Lilliefors test. The normality test results for knowledge before and after the use of the learning material based on ICT integrated CTL were obtained from the $\mathrm{L}_{\mathrm{o}}$ and $L_{t}$ values at a significant level (a) of 0.05 for $n=30$. The $\mathrm{L}_{\mathrm{o}}$ value for prior knowledge is 0.11 , while the Lo value for post-knowledge is 0.08 . From the data obtained, the value of $\mathrm{L}_{\mathrm{o}}<\mathrm{L}_{\mathrm{t}}$, means that the data of knowledge aspect of students before and after use of learning material based on ICT integrated CTL are both have a normal distribution.

After the normality test was carried out, the homogeneity test was then carried out. This is done to determine whether the data is homogeneous or not. The results of the homogeneity test for knowledge before and after the use of learning materials were obtained from the prices of $F_{c}$ and $F_{t}$. In this research, the total number of students was 30 people, so it can be obtained that the degree of freedom is $\mathrm{df}=\mathrm{n}-1=30-1=$ 29 . The $F_{t}$ value of 1.84 is obtained from the value of the degrees of freedom before and after the use of learning material, which is 29 . The value is $29 . F_{c}$ is obtained from the highest value of variance divided by the lowest value of variance. The data found that $F_{c}<F_{t}$ so that the data on the value of knowledge aspect before and after they use of learning material based on ICT integrated CTL was homogeneous.

Based on these data, the data can be declared normally distributed and homogeneous so that the statistics used are parametric statistics, namely the paired comparison test. The paired comparison test is useful to prove the significance of differences in students' knowledge before and after using the learning material based on ICT integrated CTL. The correlation coefficient (r) obtained from the equation is 0.21 .

The value of $t_{c}$ can be obtained using a correlated $t$-test so that the value of $t_{c}$ obtained is -10.80 , so the $t_{t}$ calculation used is the left-hand test. The price of $t_{t}$ obtained becomes -2.04 . In the test conducted using the left-hand side test, the $t_{c}$ value is smaller than the $t_{t}$ value $\left(t_{c}<t_{t}\right)$, then the working hypothesis is accepted. The value of $t_{h}$ is in the $H_{o}$ reject area. This shows that there is a significant difference between students' knowledge before and after using physics learning material. So, it can be concluded that the learning material based on ICT integrated CTL is effectively used to improve the knowledge aspect of students.

\section{The Effect of Learning Material Based on ICT Integrated CTL on the Skills Aspect}

Assessment of student skills before and after using physics learning material was carried out during the learning process. The value of skills is obtained from the experiment activities carried out. The assessment of skills before and after the use of learning material was carried out using an instrument sheet for assessing creative thinking skills to see students' creative thinking abilities.

The number of experiments carried out before and after the use of the learning material was three experiments. The indicators observed in the assessment consist of three. The first indicator is sparking a lot of ideas or ideas. Second, provide many ways or suggestions. Third, think of unconventional ways. Student scores were obtained from scoring with a range from 1 to 4 for each indicator observed.

Based on the value of each indicator in the skill aspect, the average of each assessment indicator can be determined. The assessment indicators include generating many ideas or concepts (MI), providing 
many ways or suggestions (MS), and thinking in unusual ways (TU). The analysis result of the value data plot for each assessment indicator can be seen in Figure 4 .

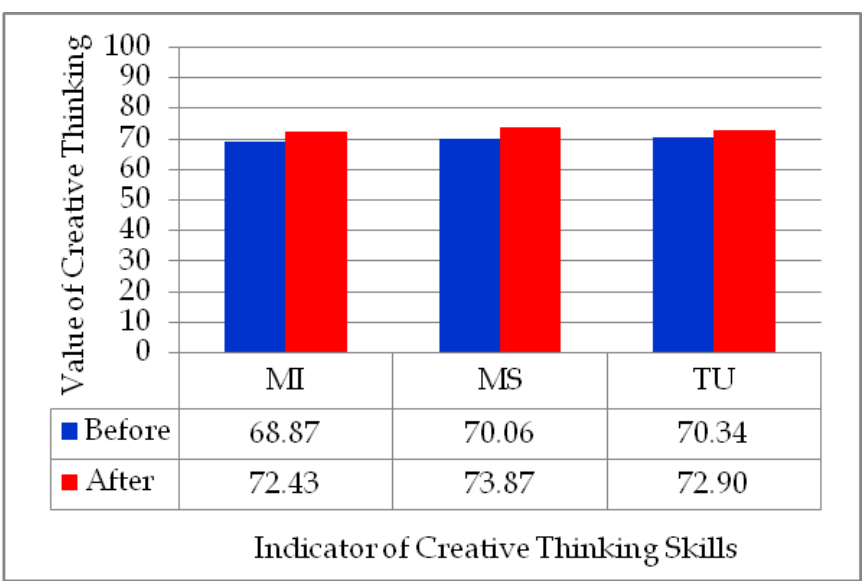

Figure 4. Value of Creative Thinking Skills

Based on the data analysis in Figure 4, it can be explained that the value of students' creative thinking skills before and after the use of the learning material based on ICT integrated CTL has increased. The significance of the difference in creative thinking skills scores before and after the use of the learning material based on ICT can be seen in Table 3 .

Table 3. Results of Skill Aspect Data Analysis

\begin{tabular}{llll}
\hline No & Statistical Parameter & $\begin{array}{l}\text { Value Skill } \\
\text { Before }\end{array}$ & $\begin{array}{l}\text { Value Skill } \\
\text { After }\end{array}$ \\
\hline 1 & Average & 52.27 & 76.26 \\
2 & Standard deviation & 5.87 & 7.39 \\
3 & Variance & 34.46 & 54.75 \\
4 & Mode & 60.00 & 81.00 \\
5 & L $_{\mathrm{o}}$ value of normality & 0.86 & 0.09 \\
& test & & \\
6 & L $_{\mathrm{t}}$ value of normality test & 0.16 & \\
7 & $\mathrm{~F}_{\mathrm{c}}$ value of homogeneity & 1.74 & \\
& test & & \\
8 & $\mathrm{~F}_{\mathrm{t}}$ value of homogeneity & 1.84 & \\
& test & & \\
9 & $\mathrm{t}_{\mathrm{c}}$ value & -10.80 & \\
10 & $\mathrm{t}_{\mathrm{t}}$ value & -2.04 & \\
\hline
\end{tabular}

Based on the skill data that has been obtained, the normality of the data must be tested first. This is done to see if the two data are normally distributed. The normality test used is the Lilliefors test. The normality test results for skills before and after using learning material that has been carried out are obtained from the prices of $L_{o}$ and $L_{t}$ at a significant level (a) of 0.05 for $n=30$. The $L_{o}$ value for skills before is 0.12 , while the $L_{o}$ value for skills after is 0.09 . From the data obtained, the value of $\mathrm{L}_{0}<\mathrm{L}_{t}$ means that the skill value data before and after learning material use are normally distributed.

After the normality test was carried out, the homogeneity test was then carried out. This is done to determine whether the data is homogeneous or not. The homogeneity test results for skills before and after the use of learning material are obtained from the prices of $F_{h}$ and $F_{t}$. In this study, the total number of students was 30 people, so it can be obtained that the degree of freedom is $\mathrm{df}=\mathrm{n}-1=30-1=29$.

The $F_{t}$ value of 1.84 is obtained from the value of the degrees of freedom before and after the use of learning material, which is 29 . The $\mathrm{F}_{\mathrm{c}}$ value is obtained from the highest value of variance divided by the lowest value of variance. The data found that $F_{c}<F_{t}$ so that the data on the value of skills aspects before and after the use of physics learning material were homogeneous.

Based on these data, the data can be declared normally distributed and homogeneous so that the statistics used are parametric statistics, namely the correlation comparison test. Correlation comparisons are useful to prove the significance of differences in student skills before and after using the learning material based on ICT integrated CTL. The analysis used is the product-moment equation. The correlation coefficient (r) obtained from the equation is 0.68 .

The value of $t_{h}$ obtained is negative, namely 24.22 , so the $t_{t}$ calculation used is the left-hand test. The price of $t_{t}$ obtained becomes -2.04 . In the test conducted using the left-hand side test, the $t_{c}$ value is smaller than the $t_{t}$ value $\left(t_{c}<t_{t}\right)$, then the working hypothesis is accepted. The value of $t_{h}$ is in the $H_{o}$ rejection region. This shows that there is a significant difference between students' skills before and after using physics learning material. So, it can be concluded that learning material based on ICT integrated CTL is effectively used to improve students' skills.

\section{Discussion}

The discussion explains the results that have been obtained in conducting the research, the constraints and limitations encountered during the research, alternative solutions, and input to overcome the problems encountered during the research. The results of the study are the results of testing the effectiveness of the learning material based on ICT integrated CTL to improve student learning outcomes. The effort made by the teacher to get good student learning outcomes is to use learning tools in the form of learning material based on ICT (Fitriani et al., 2018; Nurdyansah, 2016).

The learning materials based on ICT are all forms of material used to assist teachers in carrying out learning and learning activities in the classroom 
(Suprihati, et al. 2020). Learning material play an important role to help students achieve learning goals (Purmadi et al., 2016). This can be seen in the increase in aspects of knowledge, aspects of attitudes, and aspects of skills. Attitude towards science can mean an attitude tendency that can take the form of acceptance or rejection of science itself or physics in particular (Darmawangsa et al., 2017). Attitude aspects were assessed using observation sheets before and after using the learning material based on ICT. Observation sheets were instruments used to collect data through field observations (Ernawati et al., 2018). The attitudes assessed include discipline, confidence, hard work, cooperation, responsibility, and tolerance. Based on the observations that have been made, it is found that there is an increase in student attitudes after using the learning material based on ICT integrated CTL.

The knowledge aspect is assessed to see students' abilities by conducting tests before and after using learning material. Knowledge is the result of human sensing or the result of someone knowing about an object through their five senses (Donsu, 2017). The questions given are quite difficult which before carrying out the test, the questions are discussed first with the teacher in the field of study. The question can be used if the teacher has approved it in the field of study. A test is a tool or procedure used to find out or measure something by using a predetermined method or rule (Furwana, 2019). Students' thinking ability can be seen through the student's answer sheet after carrying out the test. The result obtained by students before and after using the learning material based on ICT integrated CTL is a significant difference, indicating an increase in students' abilities after using the learning material based on ICT integrated CTL.

Aspects of skills observed through student experiments. Skill is an ability to do something well according to the right procedure by knowing when to do it and how to do it. The indicators observed in the assessment consist of three. The first indicator is sparking a lot of ideas or ideas. Second, provide many ways or suggestions. Third, think of unconventional ways. Based on the observations made, it was found that there was an increase in students' creative thinking skills after using the learning material based on ICT integrated CTL. Based on the three analyses, the differences that occur before and after the use of the learning material can be seen.

The increase in aspects of knowledge, attitudes, and skills occurs because the learning material contains the principle of motivation in learning. The use of these learning materials based on ICT can improve student motivation (Suarman, 2017). The learning material based on ICT with a contextual approach provides opportunities for students to find concepts through events or events related to everyday life with a contextual approach (Astiti, 2019). The learning materials based on ICT have an important role in determining the achievement of educational goals (Mussani et al., 2015). Thus, it can be concluded that using the learning material based on ICT integrated CTL effectively improves students' creative thinking skills.

When conducting research, there are various limitations, so that solutions are needed to overcome these limitations. The first limitation is that the learning material made is still limited to two basic competence of grade XI in semester 2, namely basic competence 3.6 regarding mechanical waves and basic competence 3.7 regarding traveling waves and stationary waves. This is due to the limited time of researchers in making learning material for one semester. The solution to this limitation is that learning materials are made based on all the material in class XI semester 1 and semester 2 to produce complete learning material.

The second limitation is the new research stage at the product trial stage. The product trial stage is limited to one research class. This is due to the limited time of the researcher. The solution to this limitation is that learning material will be tested more broadly so that the coverage and quality of learning material are better in the future.

The third limitation is the limitation of implementation in experimental activities. This is due to the limited time of the researcher. The solution to this limitation is that in the future, experiments in the learning material being tested will be more efficient and can save time when conducting experiments.

\section{Conclusion}

From the data analysis, the conclusion can be declared from this research. The use of the mechanical wave learning material based on ICT integrated CTL positively affects the learning outcomes of grade XI students. This result indicates that the use of the learning material based on ICT integrated CTL effectively improves students' learning outcomes in grades XI in aspects of attitudes, knowledge, and critical thinking skills. These results provide a good opportunity for physics teachers to improve students' learning outcomes for the three aspects of attitude, knowledge, and creative thinking skills.

\section{Acknowledgments}

Thank you to the physics lecturer at the State University of Padang, FMIPA, who has validated the mechanical wave learning material based on ICTL integrated CTL before being tested in schools. Thank 
you to the Principal of SMAN 1 Lubuk Sikaping for allowing us to try out the use of this Learning material at school. Thanks are also conveyed to the physics teacher who has helped and facilitated the implementation of the testing activities at SMAN 1 Lubuk Sikaping.

\section{References}

Anggraini, S.D., Wahyuni, S., Aristya. (2017) . Pengembangan Modul Fisika Materi Gelom bang Berbasis Kebencanaan Alam dii SMA . Jurnal Edukasi, 6 (1). doi: https://doi.org/ 10.19184/jukasi.v4i1.5085 [Indonesian]

Asrizal, A., Amran, A., Ananda, A., \& Festiyed, F. (2018). Effectiveness of Adaptive Contextual Learning Model of Integrated Science by Integrating Digital Age Literacy on Grade VIII Students. IOP Conference Series: Materials Science and Engineering, 335, 12067.

https://doi.org/10.1088/1757$899 \times / 335 / 1 / 012067$

Asrizal, A., Festiyed, F., Sumarmin R . (2017) . Analisis Kebutuhan Pengembangan Bahan Ajar IPA Terpadu Bermuatan Literasi Era Digital untuk Pembelajaran Siswa SMP Kelas VIII . Jurnal Eksakta Pendidikan, 1 (1). doi: https://doi.org/10.24036/jep/vol1-iss1/27 [Indonesian]

Astiti, A. (2019). Pengembangan Bahan Ajar Fisika SMA Berbasis Kontekstual Pada Materi Suhu dan Kalor. Jurnal Pembelajaran Sains, 3(1).doi: http://dx.doi.org/10.17977/um033v3i1p29$\% 2034$ [Indonesian]

Azkia, N.F., Asrizal, A., Mufit, F. (2020). Pegembangan Bahan Ajar Fisika Materi Fluida Terintegrasi Literasi Baru dan Bencana Untuk Meningkatkan Hasil Belajar Siswa. Pillar Of Physic Education,13 (1). doi: http://dx.doi.org/10.24036/8054171074 [Indonesian]

Cahyono, B. A. D., Sutarto, S., \& Mahardika, I. K. (2017). Model Pembelajaran REACT (Relating, Experiencing, Applying, Cooperating, Trans fering) Disertai Media Video Kejadian Fisika Terhadap Keterampilan Proses Sains dan Hasil Belajar Siswa dalam Pembelajaran Fisika di SMA. Jurnal Edukasi, 4(3). doi: https://doi.org/ 10.19184/jukasi.v4i3.6155 [Indonesian]

Crawford. (2016). Teaching Contextually Research, Rationale and Techniques for Improving Student Motivation and Achievment in Mathematics and Science. Waco, Texas: CORD Communications: Inc.

Darmawangsa, R. Astalini, \& Kurniawan, D, A. (2017). Pengembangan Instrumen Sikap Siswa Sekolah
Menengah Atas terhadap Mata Pelajaran Fisika. Jurnal Pendidikan Fisika. 6(1). doi: https:// doi.org/10.26618/ipf.v6i1.1136 [Indonesian]

Desnita, A., Putra, A., Hamida, S. (2021). Quality Test of Student Worksheets Based on Contextual Teaching And Learning for Class XI High School Physics. Jurnal Penelitian Pendidikan IPA. 7(1). doi: 10.29303/jppipa.v7i1.600

Donsu, J.D.T. (2017). Metodologi Penelitian. Yogyakarta: Pustakabarupress. [Indonesian]

Ernawati, E., Sabdaningtyas, L., Pargito, P., Ambarita, A. (2018). Development of Performance Assessment Instrument in Thematic Learning of 4th Grader Elementary School. Journal of Education and Practice, 9 (26). doi: https:// doi.org/ 10.7176/JEP

Fitriani, F., Hidayatulloh, R.M.F., Arga, H.S.P. (2018). Use of Learning Media ICT-Based to Improve Motivation and The Result of Learning Science in Solar System Materials. Journal of Elementary Education, 01 (06). Retrieved from: https://journal.ikipsiliwangi.ac.id/index.php/c ollase/article/view/2300

Furwana, D. (2019). Validity and Reliability of TeacherMade English Summative Test at Second Grade of Vocational High School 2 Palopo. Language Circle: Journal of Language and Literature, 13 (2). doi: https://doi.org/10.15294/ lc.v13i2.18967

Irianto, A. (2017). Statistik Konsep dasar dan Aplikasinya. Jakarta: Kencana Prenada Media Group.

Kadmayana, K., Halim, H., Mustafa, M., Ilyas, S. (2021). Impact of Contextual Teaching Learning Model to Science Process Skills and Scientific Attitudes of Students. Jurnal Penelitian Pendidikan IPA, 7 (3). doi:https://doi.org/10.29303/jppipa.v7i3.714

Khairunnisa, I., Desnita, D, Putra, A., \& Hidayati H. (2020). Analisis Sajian Buku Teks Pelajaran Fisika SMA Kelas XII Semester 2 Terkait Komponen Pendekatan Contextual Teaching And Learning (CTL). Pillar of Physics Education, 13(1), 17-24. doi: http://dx.doi.org/10.24036/7964171074 [Indonesian]

Musanni, Susilawati, Hadiwijaya, A. (2015). Pengembangan Bahan Ajar Fisika SMA Berbasis Learning Cycle (LC) 3E Materi Pokok Teori Kinetik Gas dan Termodinamika. Jurnal Penelitian Pendidikan IPA. 1(1). doi: https://doi.org/10.29303/jppipa.v1i1 [Indonesian]

Novri., Z. Zulfah.,A. Astuti. (2018). Pengaruh Strategi React (Relating, Experiencing, Applying, Cooperating , Transfering) Terhadap Kemam puan Pemahaman Konsep Matematis Siswa Kelas VII SMP Negeri 1 Bangkinang. Jurnal 
Pendidikan Matematika, 2 (2). doi: https:// doi.org/10.31004/cendekia.v2i2.52 [Indonesian]

Nurdyansyah, N., Riananda, L. (2016). Developing ICTBased Learning Model to Improve Learning Outcomes IPA of SD Fish Market in Sidoarjo. Jurnal Teknologi Pendidikan, 1 (2). Retrieved from: https://journal.unesa.ac.id/index.php/jtp/articl e/view/1137

Olayinka, A. R. B. (2016). Effects of Instructional Materials on Secondary Schools Students' Academic Achievement in Social Studies in Ekiti State, Nigeria. World Journal of Education, 6(1), doi: https://doi.org/10.5430/wje.v6n1p32

Permadi, A., Surjono, H. (2016). Pengembangan Bahan Ajar Berbasis Web Berdasarkan Gaya Belajar Siswa Untuk Mata Pelajaran Fisika. Jurnal Inovasi Teknologi Pendidikan, 3 (2). doi : https://doi.org/ 10.21831/jitp.v3i2.8285 [Indonesian]

Redhana , I, E. (2019). Mengembangkan Keterampilan Abad Ke-21 Dalam Pembelajaran Kimia. Jurnal Pendidikan Kimia, 13 (1). Retrieved from: https:// journal.unnes.ac.id/nju/index.php/JIPK/article $\angle$ view/17824 [Indonesian]

Rizka, N. (2014). Pengaruh Penerapan Strategi Relating, Experiencing, Applying, Cooperating, Transfer ring Terhadap Kemampuan Pemahaman Konsep Fisika Siswa Kelas X SMAN 2 Payakumbuh. Jurnal Pendidikan Matematika, 3(2). Retrieved from: http:// ejournal. unp. ac.id/students/ index. php/ pmat/article/view/6237/0 [Indonesian]

Shidiq, S, A., Darvina, Y., Desnita, D., dan Asrizal, A. (2020). Pembuatan Buku Ajar Terintegrasi Pembelajaran Kontekstual dan Literasi Lingkungan Materi Gelombang dan Alat Optik Untuk Siswa SMA Kelas XI. Pillar Physics Education 13 (2). doi: http://dx.doi.org/ 10.24036/8620171074 [Indonesian]

Suarman, S,. Suryati, M. (2017). The Effect of Using ICT Based on Learning Media to Students' Learning Motivation. Proceeding of The 1st UR International Conference on Educational Sciences

Sugiyono. (2017). Metode Penelitian Kuantitatif, Kualitatif dan RED. Bandung: Alfabeta. [Indonesian]

Suprihati, S., Manik, Y. (2020). Guru Menginovasi Bahan Ajar Sebagai Langkah Untuk Meningkat kan Hasil Belajar Siswa. Jurnal Promosi, 8 (1). doi: http://dx.doi.org/10.24127/pro.v8i1.2868 [Indonesian]

Sutopo. (2016). Students' Unserstanding of Fundamental Concepts of Mechanical Wave. Jurnal Pendidikan Fisika Indonesia. 12 (1). doi: 10.15294/jpfi.v12i1.4264
Tanzeh, A. (2011). Metodologi Penelitian Praktis. Yogyakarta: Teras. [Indonesian]

Yana, A., Antasari, L., Kurniawan, B. (2019). Analisis Pemahaman Konsep Gelombang Mekanik Melalui Aplikasi Online Quizizz. Jurnal Pendidikan Sains Indonesia, 7 (2). doi: 10.24815/jpsi.v7i2.14284 [Indonesian]

Usman, E.A., Asrizal, A. (2020). Results of Validity and Practicality Test of ICT-Science Learning Material with Learning Cycle Model for Improving Digital Literacy of Students. International Journal of Progressive Sciences and Technologies, 23 (2). doi: 10.52155/ijpsat.v23.2.2387

Zulfadli, D., Desnita, D., Festiyed, F., Syadriani. (2019). Analisis Sajian Buku Ajar Fisika SMA Kelas X Semester 1 Terkait Komponen Contextual Teaching and Learning (CTL). Pillar of Physics Education, 12(3).doi: http://dx.doi.org/ 10.24036 \7037171074 [Indonesian] 